\title{
Role of early post-settlement mortality in setting the upper depth limit of ascidians in Florida epifaunal communities
}

\author{
James E. Dalby, Jr*, Craig M. Young \\ Department of Biological Science, Florida State University, Tallahassee, Florida 32306, USA \\ and \\ Division of Marine Science, Harbor Branch Oceanographic Institution, 5600 Old Dixie Highway, Fort Pierce, Florida 34946 , \\ USA
}

\begin{abstract}
At 3 sites in Florida, USA, the communities of marine sessile invertebrates are dominated by oysters (Crassostrea virginica) in the mid-intertidal zone, and by ascidians (several species) in the low intertidal and subtidal zones. Our experiments tested the hypotheses that the upper depth limit of ascidians is set by (1) predation by oysters on larvae, (2) larval zonation, and (3) early post-settlement mortality. Hypothesis 1 was tested by monitoring ascidian recruitment on the shells of dead and living oysters placed in both the oyster and ascidian zones. Because recruitment of all ascidian species was confined to oysters placed in the ascidian zone, we concluded that the upper depth limit of these ascidians cannot be due solely to predation on larvae by oysters. Hypotheses 2 and 3 were tested by monitoring the recruitment of ascidians on settling plates fixed in the 2 zones, and on plates floating at 2 depths in the water column. In the 'fixed' experiments, recruitment of all ascidian species was confined to the ascidian zone. In the 'floating' experiments, the number of recruits of Diplosoma glandulosum did not differ between shallow and deep plates, and recruitment of Styela plicata was confined to shallow plates. Thus, we concluded that early post-settlement mortality is a major factor setting the upper depth limit of these 2 species. We vertically transplanted 2 ascidians (S. plicata, Botryllus planus) and found that the survivorship of both was greater in the ascidian zone than in the oyster zone. Thus, further support was gained for the post-settlement mortality hypothesis.
\end{abstract}

\section{INTRODUCTION}

One obvious distribution pattern in the marine benthos is the intertidal zonation of sessile invertebrates. Some of the earliest field experiments done in ecology were aimed at identifying the processes that cause zonation. These emphasized the importance of post-settlement events, such as physical factors (Connell 1961a, b), predation (Connell 1961a, Dayton 1971, Paine 1974, Menge 1976, Underwood 1980), and competition (Connell 1961b, Dayton 1971, Menge 1976). More recent experiments provide evidence that intertidal limits are influenced by pre-settlement events, such as larval pre-emption of space (Denley \& Underwood 1979), larval zonation (Grosberg 1982), larval predation (Gaines \& Roughgarden 1985, 1987), and larval settlement preferences (Raimondi 1988, 1991).

\footnotetext{
- Present address: Zoology Department, Melbourne University, Parkville, Victoria 3052, Australia
}

Recent field experiments, aimed at determining the causes of spatial distribution patterns in ascidians, have considered the roles of both pre- and post-settlement events. Some studies highlight the significance of postsettlement events, such as physical factors, predation, and competition (Young \& Chia 1984, Young 1985. 1989, Keough \& Downes 1986, Davis 1987). Others have found that pre-settlement processes, such as larval transport, larval behavior, and larval predation (Young \& Chia 1984, 1987, Olson 1985, Keough \& Downes 1986, Davis 1987, Olson \& McPherson 1987. Svane 1987, Svane \& Young 1989, Stoner 1990, Havenhand \& Svane 1991) are significant.

On the coast of Florida, USA, ascidians occur in the subtidal and low intertidal attached to mangrove roots, sea grass blades, mollusc shells, worm tubes, sea walls, or can be found unattached and drifting on the bottom (Rudloe 1971, Odum et al. 1982, Young 1989). Oysters (Crassostrea virginica) usually occur at shallower depths on intertidal sand bars, but are also found at the 
same depths and on the same substrata where ascidians live (Menzel \& Nichy 1958, Menzel et al. 1958, 1966, Nichy \& Menzel 1960, Odum et al. 1982).

What factors set the upper depth limit of ascidians in these communities? Our experiments test the hypotheses that the depth limit is determined by (1) predation by oysters on larvae; (2) larval zonation; or (3) early post-settlement mortality.

Below, 'settlement' refers to the attachment of a larva to a substratum and its concomitant metamorphosis, whereas 'recruitment' is the survival of the early juvenile until seen by an investigator (sensu Keough \& Downes 1982).

\section{MATERIALS AND METHODS}

Study sites. This study was carried out in Florida, USA, at 2 sites in the Indian River Lagoon near Fort Pierce (Little Jim Bridge $=$ LJB, Harbor Branch Oceanographic Institution marina $=\mathrm{HBM}$ ), and at 1 site in the northern Gulf of Mexico near Carrabelle (Florida State University Marine Laboratory boat basin $=$ FSU). Fort Pierce and Carrabelle are $550 \mathrm{~km}$ apart the 2 Fort Pierce sites are separated by $7 \mathrm{~km}$.

Photography. Sessile organisms (including ascidians) occupying sea walls and settling plates were photographed on Kodachrome color slide film (ASA 64) using a Nikonos 5 camera and Whale strobe. To calculate the percent cover occupied by each species, we projected each slide on 1 of 8 randomly chosen grids of 100 random points, and recorded the species which appeared under each point. Sutherland \& Karlson (1977) and Mook (1980) found that 75 and 80 random points, respectively, provided adequate estimates of the percent cover of species on plates of similar size. Because many species are epizoic, it was possible to have more than $100 \%$ cover for a given slide.

Zonation. To document zonation of oysters and ascidians at LJB, we took 5 photoquadrats in a vertical line at each of 7 locations along the sea wall, using a 1:6 close-up lens and framer and $28 \mathrm{~mm}$ lens (field of view $144 \times 216 \mathrm{~mm}$ ). At FSU, we took 3 photoquadrats in a vertical line at each of 10 locations along the sea wall, using a 1:3 extension ring and framer with a $35 \mathrm{~mm}$ lens (field of view $71 \times 106 \mathrm{~mm}$ ). Photos were taken in June 1986 (LJB) and April 1988 (FSU). We deemed it unnecessary to photograph zonation at HBM, since the pattern at this site was no different from that at the other Fort Pierce site, LJB.

Placement of settling plates. In the experiments described below, plates were mounted on nails hammered into sea wall fissures (LJB); or suspended along a cement dock from PVC pipes (HBM), or wooden beams (FSU). An arbitrary datum was estab- lished at both Fort Pierce sites since, unlike FSU, neither had tidal gauges. Plates were mounted in the oyster and ascidian zones such that their upper edges were positioned at tidal heights of +63 and $0 \mathrm{~cm}$ (LJB), +75 and $0 \mathrm{~cm}$ (HBM), and +42 and $-70 \mathrm{~cm}$ (FSU). Each plate positioned in the oyster zone was paired with a plate in the same vertical line in the ascidian zone.

Larval predation experiment. To test the hypothesis that the upper depth limit of ascidians at LJB is due to predation by Crassostrea virginica on larvae, we monitored ascidian recruitment on the shells of living and dead oysters placed in the oyster and ascidian zones.

We haphazardly collected 72 oysters (mean height \pm $\mathrm{SD}=83 \pm 18 \mathrm{~mm}$ ) from HBM, removed all epibiota from their shells, and randomly divided them into 2 groups of 36 . We then removed the bodies from the shells of all individuals of 1 group, and replaced them with cement. Next, the dead oysters were randomly divided into 6 groups of 6 , as were the living ones. Each group of 6 oysters was then cemented onto a cement plate $(18 \times 20 \times 2 \mathrm{~cm})$ in a $2 \times 3$ array. Each oyster was haphazardly oriented with its lower value closest to the plate.

The 12 plates (each occupied by a group of 6 oysters) were then mounted on the sea wall fissures at LJB. Three of the 6 living groups were set in the oyster zone, and the other 3 were placed in the ascidian zone. The 6 dead groups were distributed in the same way. Vertical pairs of living and dead groups were horizontally interspersed.

Ascidians that recruited on oyster shells were counted at the end of the $18 \mathrm{~d}$ experiment. We checked the oysters daily to see if they were feeding.

Fixed experiments. To determine whether the absence of ascidians in the oyster zone is due to a lack of recruitment, we monitored recruitment on clay tiles $(14.5 \times 14.5 \times 2 \mathrm{~cm})$ secured in the 2 zones. The smooth surface of each plate faced away from the sea wall, and was the surface we monitored for ascidian recruitment. To minimize possible edge effects, we used a 1:3 framer (which covered only the mid-section of each plate) when photographing ascidians on plates. The same framer was also used to outline the area in which ascidians were counted

At both LJB and FSU, 16 plates were positioned in the oyster zone, and 16 in the ascidian zone; at HBM there were 5 in each zone. The horizontal distance between successive plates was 75 (LJB), 4.5 (HBM), and $62 \mathrm{~cm}$ (FSU).

At LJB and FSU, the 16 plates within each zone were divided equally into 4 treatments: (1) removal of compound ascidians only, (2) removal of solitary ascidians only, (3) removal of all ascidians, and (4) no removals 
(control). These treatments were part of a concurrent study designed to test the tolerance of oysters to ascidian overgrowth (Dalby 1988).

Experiments were run in March to September 1987 (LJB), August to September 1987 (HBM), and October 1986 to August 1987 (FSU). At LJB, plates were photographed and ascidians removed every 2 to $4 \mathrm{wk}$. At HBM, plates were examined once at the end of the $16 \mathrm{~d}$ experiment. At FSU, ascidians were counted and removed every 1 to $2 \mathrm{wk}$ and photos taken every 3 to 5 wk. Photos were always taken prior to ascidian removal.

Floating experiments. In the fixed experiments, we observed that ascidian recruitment was confined to the ascidian zone. The lack of recruitment in the oyster zone may be due to larval zonation (i.e. larvae are present only at low depths) or early post-settlement mortality (i.e. larvae are present at all depths but die after settlement in the oyster zone). To test these hypotheses, we monitored ascidian recruitment on clay tiles $(14.5 \times 14.5 \times 2 \mathrm{~cm})$ floating at 2 depths.

Plates were attached to rectangular racks $(100 \mathrm{~cm}$ wide, $75 \mathrm{~cm}$ tall) made of PVC pipe (25 mm diameter). On each rack, 5 plates were hung along the upper pipe, and 5 along the lower pipe. The horizontal distance between successive plates was $45 \mathrm{~mm}$.

Each rack was held afloat by 6 styrofoam floats (15 cm diameter) attached along the upper pipe; each rack was connected by a rope to a cement block on the bottom. Ropes were slack enough to allow free vertical movement of racks with tidal flux. When the surface of the water was still, the upper edges of the shallow and deep plates were 21 and $96 \mathrm{~cm}$ from the surface, respectively. During low tides, the deep plates never came within $1 \mathrm{~m}$ of the bottom, and were thus inaccessible to benthic predators. The average depths in which the experiments were run were $3 \mathrm{~m}$ (HBM) and $4 \mathrm{~m}$ (FSU). At HBM, 5 racks were deployed for $16 \mathrm{~d}$ in August-September 1987. At FSU, 6 racks were deployed for $34 \mathrm{~d}$ in May-June 1987.

At HBM, ascidians were counted after plates were recovered and dried out; at FSU, counts were made from photographs taken in situ. For the HBM experiment, we counted only those colonies that appeared on the smooth surface of each plate, as those on the rough surface were not easily discerned. For the FSU experiment, there was no such difficulty, so both plate surfaces were considered.

Transplant experiments. To test the hypothesis that ascidians are absent from the oyster zone because they cannot survive there, we transplanted individuals of 2 ascidian species to the oyster zone with control individuals in the ascidian zone.

Styela plicata: We haphazardly collected 54 specimens of $S$. plicata (mean height $\pm S D=45 \pm 7 \mathrm{~mm}$ ) from LJB and randomly divided them into 6 groups of 9 individuals. Each group was glued (Krazy Glue) to a cement plate $(18 \times 20 \times 2 \mathrm{~cm})$ in a $3 \times 3$ array. Three plates were then mounted in each zone at LJB. The distance between successive plates within each zone was $75 \mathrm{~cm}$. Ascidians were monitored daily over a $41 \mathrm{~d}$ period in June-July 1986.

At FSU, Styela plicata were obtained by hanging 8 clay tiles $(14.5 \times 14.5 \times 2 \mathrm{~cm})$ at the level of the ascidian zone in November 1987 Once plates became fouled by $S$. plicata ( 3 to $10 \mathrm{~mm}$ tall), 4 plates were suspended at the level of the oyster zone, and the other 4 were left in the ascidian zone where they served as controls. The distance between successive plates within each zone was 1 to $3 \mathrm{~m}$. The experiment began in December, and individuals on all plate surfaces (smooth side, rough side, edges) were checked monthly until March 1988

In both experiments, we counted the number of living and dead ascidians at each check. Dead individuals were recognized when necrotic tissue appeared or when the ascidians did not contract when poked.

Botryllus planus: At HBM, we collected 54 colonies of $B$. planus (<30 mm diameter) and randomly divided them into 6 groups of 9 . Each group was then strapped to a cement plate $(18 \times 20 \times 2 \mathrm{~cm})$ in a $3 \times 3$ array using rubber bands. The 6 plates were then mounted in the ascidian zone for $1 \mathrm{wk}$ to allow colonies to secure themselves to plates.

Next, 3 of the 6 plates were moved up to the oyster zone. Within each zone, the distance between successive plates was $75 \mathrm{~cm}$. The experiment was run in July 1986 and ended after $24 \mathrm{~h}$ when the colonies were checked for the first time. Dead colonies were identified by their blackened appearance.

\section{RESULTS}

\section{Zonation}

At both LJB and FSU, an oyster (Crassostrea virginica) zone was found above an ascidian zone (Fig. 1). We saw the same pattern at HBM.

Bingham (1990) identified 32 species of ascidians at our Fort Pierce sites. We found 6 species at FSU (Table 1). Many other sessile taxa are present at the 2 Fort Pierce sites (Mook 1983a) and at FSU (Menzel 1971).

\section{Larval predation experiment}

Ascidians did not recruit on the shells of either dead or living oysters placed in the oyster zone. However, 3 species (Botryllus planus, Didemnum sp., Polyan- 

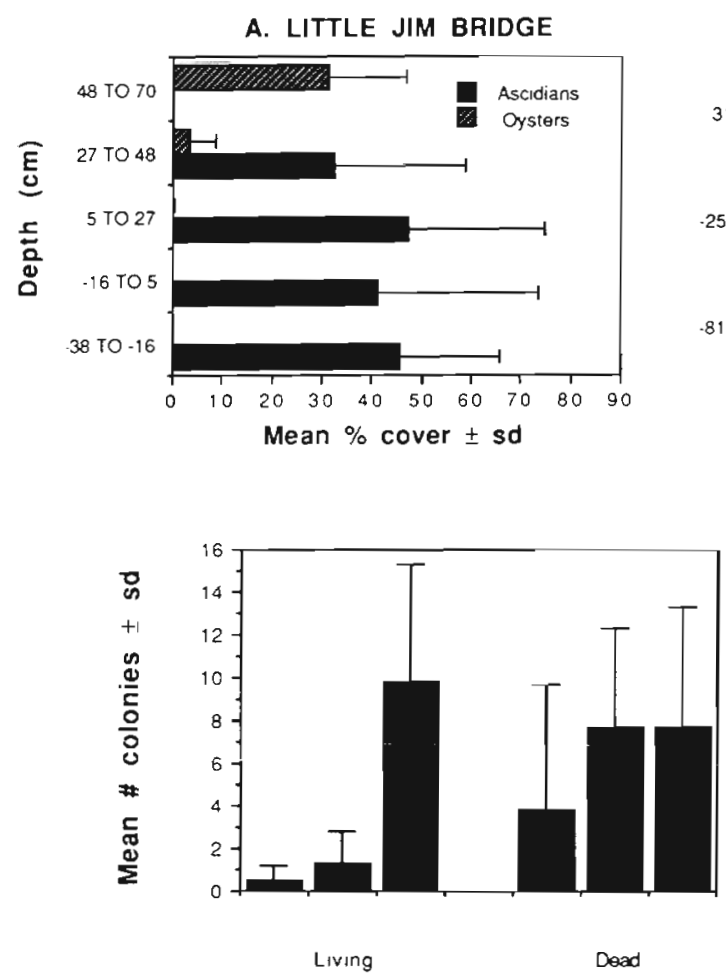

Fig. 2. Didemnum sp. Recruitment on shells of dead and living oysters in the ascidian zone at LJB. Each bar represents a group of oysters on a plate. The difference between dead and living oysters was nonsignificant ( $t$-test: $\mathrm{df}=4, \mathrm{p}=0.479$ )

drocarpa zorritensis) recruited on oysters placed in the ascidian zone

Some of the living oysters placed in the ascidian zone were not used in analyses because we never saw them feeding (i.e. valves were always closed) during the experiment. As a result, instead of analyzing data for 6 oysters per plate, we analyzed data for 2 oysters on 1 plate, 4 on the second, and 5 on the third.

The difference in the number of Didemnum sp. recruits ( 2 to $10 \mathrm{~mm}$ colonies) between dead and living oysters in the ascidian zone was nonsignificant (Fig. 2). The amount of recruitment of Botryllus planus and Polyandrocarpa zorritensis was inadequate (mean no. colonies oyster ${ }^{-1}<1$ ) for analyses.

\section{Fixed experiments}

Ascidians never recruited on plates set in the oyster zone at any of the 3 sites. The numbers of ascidian species that recruited on plates in the ascidian zone were 14 at LJB, 1 at HMB, and 6 at FSU (Table 1).

Styela plicata numbers on control plates at FSU peaked in May 1987 and crashed in July 1987 (Fig. 3), the latter occurring during a time of high water temperatures (Dalby 1988).

\section{B. FSU MARINE LAB}

Fig. 1. Vertical zonation of oysters and ascidians on sea walls at (A) LJB and (B) FSU
Table 1. Ascidians $(\mathrm{C}=$ colonial, $\mathrm{S}=$ solitary) that recruited on fixed plates at LJB, HBM, and FSU

\begin{tabular}{|c|c|c|c|c|}
\hline Taxa & $\mathrm{C} / \mathrm{S}$ & LJB & HBM & FSU \\
\hline \multicolumn{5}{|l|}{ Order Aplousubranchia } \\
\hline Clavelina oblonga & C & $\mathrm{x}$ & & \\
\hline Didemnum conchyliatum & $\mathrm{C}$ & $\mathrm{x}$ & & \\
\hline Didemnum sp. & $\mathrm{C}$ & $x$ & & \\
\hline Diplosoma glandulosum & $\mathrm{C}$ & $\mathrm{x}$ & $x$ & \\
\hline Diplosoma macdonaldii & $\mathrm{C}$ & $\mathrm{x}$ & & \\
\hline Diplosoma sp. & $\mathrm{C}$ & & & $\mathrm{x}$ \\
\hline Eudistoma capsulatum & $\mathrm{C}$ & $\mathrm{x}$ & & \\
\hline Trididemnum savignii & $\mathrm{C}$ & $\mathrm{x}$ & & \\
\hline \multicolumn{5}{|l|}{ Order Phlebobranchia } \\
\hline Ascidia curvata & $S$ & $\mathrm{x}$ & & \\
\hline Ecteinascidia turbinata & $\mathrm{C}$ & & & $\mathrm{x}$ \\
\hline Perophora viridis & $\mathrm{C}$ & & & $\mathrm{x}$ \\
\hline \multicolumn{5}{|l|}{ Order Stolidobranchia } \\
\hline Botryllus planus & $\mathrm{C}$ & $\mathrm{x}$ & & \\
\hline Microcosmus exasperatus & $\mathrm{S}$ & $\mathrm{x}$ & & \\
\hline Molgula occidentalis & S & $\mathrm{x}$ & & $\mathrm{x}$ \\
\hline Polyandrocarpa zorritensis & $\mathrm{C}$ & $\mathrm{x}$ & & \\
\hline Styela partita & $\mathrm{S}$ & & & $\mathrm{x}$ \\
\hline Styela plicata & $\mathrm{S}$ & $\mathrm{x}$ & & $\mathrm{x}$ \\
\hline Symplegma viride & $\mathrm{C}$ & $\mathrm{x}$ & & \\
\hline
\end{tabular}

Floating experiments

The only ascidian species to appear on floating plates at HBM was Diplosoma glandulosum. After $16 \mathrm{~d}$, the difference in the number of colonies (2 to $5 \mathrm{~mm}$ ) between shallow and deep plates was nonsignificant (Fig. 4A).

Styela plicata was the only ascidian species to recruit on floating plates at FSU. Twenty-five days into the experiment, ascidians were present only on the shallow plates. The same pattern was observed when the experiment was ended on Day 34 (Fig. 4B). At this time, ascidians were $\leq 10 \mathrm{~mm}$ in size. Because the ascidians were so crowded, it was difficult to distinguish individuals in photographs, so siphons were counted instead. 


\section{Transplant experiments}

Styela plicata, LJB. The data that we analyzed were the number of days that each individual survived. One individual disappeared before the end of the experiment in the oyster zone, as did 7 in the ascidian zone. Since we noticed that the grip of these 8 individuals was weakening with each inspection, we believe these individuals fell of the plates as a result of glue dissolution. We doubt that fish preyed on them since only juvenile $S$. plicata are known to be vulnerable (Mook 1983b); our experiment used adult animals only. For these 8 individuals, we took the number of days of survival to be the number of days present.

Thirteen of the 27 ascidians placed in the ascidian zone were still alive at the end of the $41 \mathrm{~d}$ experiment, so for these individuals we took the number of days of survival to be 41 . None of those placed in the oyster zone were alive after $41 \mathrm{~d}$.

The mean number of days that Styela plicata survived in the ascidian zone was significantly greater than that in the oyster zone (Fig. 5A).

Styela plicata, FSU. The number of young S. plicata remaining in the oyster zone after 3 mo was 0 ; in the ascidian zone, there was a dramatic increase in abundance due to recruitment (Fig. 5B). Dead individuals were never seen. It is probable that the loss of young

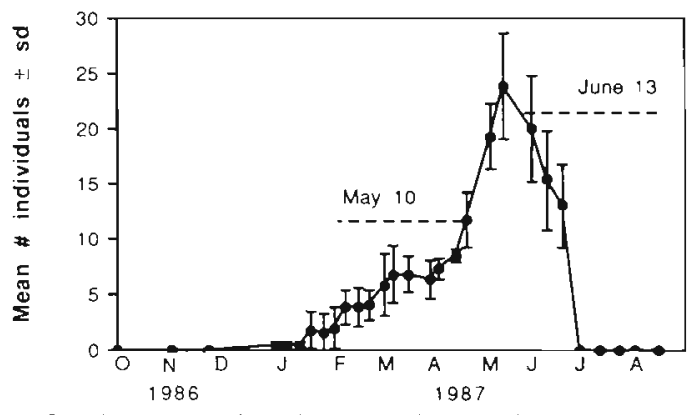

Fig. 3. Styela plicata abundance in the ascidian zone at FSU in 1986-87. (The concurrent floating experiment ran from May 10 to June 13)

ascidians in the oyster zone was due to death rather than detachment, since individuals are known to detach only when under the weight of dense aggregations of large conspecifics (Sutherland 1978).

We cannot declare that survivorship was greater in the ascidian zone than in the oyster zone because we could not distinguish transplanted individuals from ones that recruited during the experiment. Nevertheless, the observation that there were no survivors beyond $3 \mathrm{mo}$ in the oyster zone is consistent with our notion of differential survivorship.

Botryllus planus. After $1 \mathrm{~d}$, all 27 B. planus colonies placed in the oyster zone at LJB died, whereas all 27 of those in the ascidian zone survived beyond $3 \mathrm{wk}$.
Fig. 4. Recruitment of (A) Diplosoma glandulosum at HBM, and (B) Styela plicata at FSU, on floating plates. In (A), the difference in recruitment between shallow and deep plates was nonsignificant (Paired $t$ test: $\mathrm{df}=4, \mathrm{p}=0.215$ )

\section{A. DIPLOSOMA GLANDULOSUM}

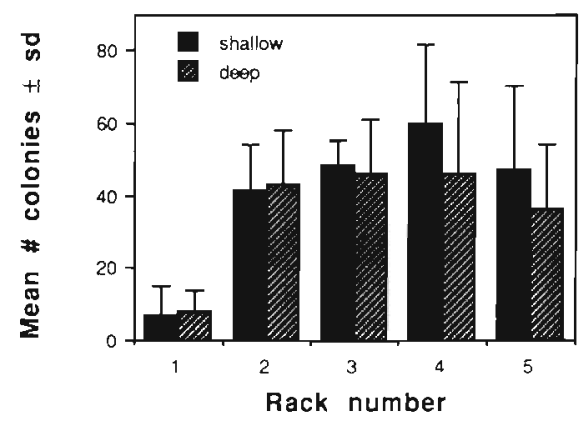

A. LITTLE JIM BRIDGE

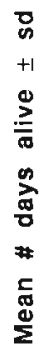

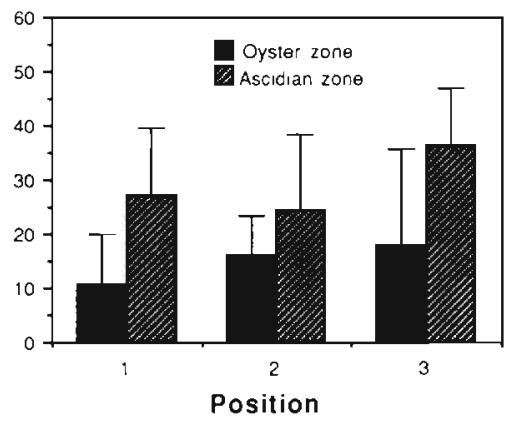

\section{B. STYELA PLICATA}

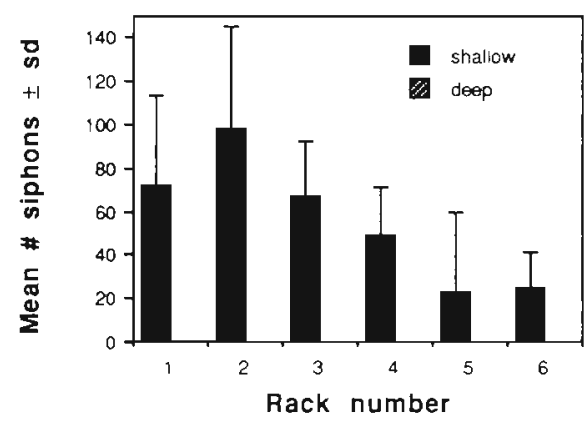

B. FSU MARINE LAB

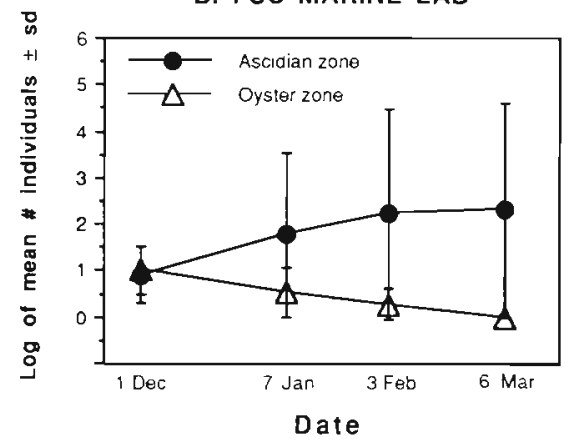

Fig. 5. Styela plicata. (A) Survivorship when transplanted to the oyster and ascidian zones at LJB. Survivorship in the ascidian zone was significantly greater than that in the oyster zone (Paired $t$-test: $\mathrm{df}=2, \mathrm{p}=$ 0.04). (B) Change in abundance when transplanted to the 2 zones at FSU 


\section{DISCUSSION}

When experimental surfaces (oyster shells, settling plates) were placed in the oyster and ascidian zones at our 3 study sites, recruitment of all ascidians was confined to surfaces set in the ascidian zone. Thus, there is no evidence that the absence of ascidians in the oyster zone is purely the result of predation on larvae by oysters. At HBM, the difference in the number of Didemnum sp. recruits between dead and living oysters in the ascidian zone was nonsignificant. Thus, there is no reason to believe that predation on larvae by oysters contributes to the absence of Didemnum sp. in the oyster zone at HBM. Young (1990) discusses problems in detecting larval predation effects.

At HBM, the number of colonies of Diplosoma glandulosum that appeared on plates floating near the surface did not differ from the number on plates floating at a lower depth. This result supports the idea that early post-settlement mortality is a factor responsible for the absence of this ascidian in the oyster zone. It also suggests that the absence is partly due to reduced settlement: the oyster zone is exposed for longer periods than the ascidian zone, and thus there is less opportunity for settlement in the former than in the latter.

At FSU, Stylea plicata recruited on plates floating near the surface and not on ones floating at a lower depth. This result suggests that the absence of this ascidian in the oyster zone is due to early postsettlement mortality. It also suggests that $S$, plicata settle in the ascidian zone when the tide is low.

The lack of Styela plicata recruitment on the deep floating plates could have been due to suppressed growth and/or survivorship rather than reduced settlement. At low depths, fish predation could be more intense, and there might be less phytoplankton food available. However, these possibilities are unlikely since S. plicata living on plates fixed in the ascidian zone were at peak levels of abundance during the floating experiment (Fig. 3).

Based on the literature, we did not expect the recruitment of Styela plicata on floating plates to be confined to the shallow level. Yamaguchi (1970) found that settlement of this species in Japan on floating glass slides did not differ between 0 and $2 \mathrm{~m}$ depth. In Italy, S. plicata colonized shaded surfaces of settling plates more readily than unshaded ones (Tursi \& Mataresse 1981). From this observation, one might predict less recruitment on shallow (more insolated) plates than deep ones

Our experiments have not addressed the possible role of larval settlement preferences in setting ascidian depth distributions. For example, the settlement of some barnacle species is induced by algae and inver- tebrates that occupy the same zone (Strathmann et al. 1981. Raimondi 1988). Perhaps the larvae of Diplosoma glandulosum and Styela plicata cue on certain organisms that reside in the ascidian zone.

Survivorship of Styela plicata and Botryllus planus transplanted to the oyster zone was less than that in the ascidian zone. Processes that kill ascidians at shallow depths include desiccation, insolation, exposure to freshwater, freezing, and predation (Millar 1971, Jokiel 1980, Olson 1983, Dalby 1989, Young 1989). By contrast, the ascidian Pyura stolonifera, which forms a band in the intertidal zone on some shores in the southern hemisphere (Stephenson \& Stephenson 1972, Dakin 1987), is thought to suffer greater mortality in the subtidal than in the intertidal zone because of subtidal predators (Paine \& Suchanek 1983, but see Underwood \& Fairweather 1986)

Styela plicata transplanted to the oyster zone at FSU probably froze to death. In winter at this site, tides reach their lowest annual heights (NOAA Tide Tables). In addition, northerly cold fronts depress tides below their predicted levels, and cause air temperatures to drop below the freezing point. Likewise, the ascidian Molgula occidentalis, which occurs on intertidal sand bars near FSU, freezes to death during winter low tides (Young 1989). Fresh water may have also killed $S$. plicata, as surface salinities occasionally dropped to 7 ppt at this site (Dalby 1988). Although the snail Melongena corona preys on S. plicata in the intertidal zone of sandy shores (Dalby 1989), we doubt that it contributed to the mortality that we observed in our transplant experiment since we have never seen this snail on sea walls at FSU.

Given that our transplanted adult/juvenile ascidians were unable to survive in the oyster zone, it seems even less likely that newly settled larvae (of the same species) would survive either. The higher surface area to volume ratio of newly settled larvae (due to their smaller size but similar shape) leaves them more vulnerable to physical stresses such as desiccation.

Our study has examined both pre- and post-settlement events in setting depth limits of intertidal/subtidal invertebrates. While a recent wave of studies emphasize the importance of pre-settlement events in determining these limits (see 'Introduction'), in our case we find that post-settlement events are of major significance.

Acknowledgements. This research was done in partial fulfillment of J.E.D.'s M.S. degree at Florida State University. We thank W Herrnkind, M. Keough, H. Koyama, R. Mariscal, P. Raimondi, and W. Menzel for reviewing the thesis/manuscript. We thank B. Bingham, L. Dilling, P. Pape, and P. Wilber for field assistance. We are grateful for advice on mechanical aspects of experimental design given by $T$ Baumker, $L$. Cameron, and the FSU Marine Lab staff. J.E.D. was funded by 
a James Lougheed Award from the Alberta Heritage Scholarship Fund and by a FSU Marine Lab Assistantship; C.M.Y was funded by National Science Foundation Grant OCE8544845 . This is Harbor Branch contribution \#857

\section{LITERATURE CITED}

Bingham, B. L. (1990). The ecology of epifaunal communities on prop roots of the red mangrove, Rhizophora mangle. Ph.D. thesis, Florida State Univ., Tallahassee

Connell, J. H. (1961a). Effects of competition, predation by Thais lapillus, and other factors on natural populations of the bamacle Balanus balanoides. Ecol. Monogr. 31: $61-104$

Connell, J. H. (1961b). The influence of interspecific competition and other factors on the distribution of the barnacle Chthamalus stellatus. Ecology 42: 710-723

Dakin, W. J. (1987). Australian seashores. Angus and Robertson, London

Dalby, J. E. Jr (1988). Distribution and abundance patterns of oysters and ascidians in Florida fouling communities: variable outcomes of competition and role of early post-settlement mortality. M.S. thesis, Florida State Univ., Tallahassee

Dalby, J. E. Jr (1989). Predation of ascidians by Melongena corona (Neogastropoda: Melongenidae) in the northern Gulf of Mexico. Bull. mar Sci. 45: 708-712

Davis, A. R. (1987). Variation in recruitment of the subtidal colonial ascidian Podoclavella cylindrica (Quoy and Gaimard): the role of substratum choice and early survival. J. exp. mar Biol. Ecol. 106: 57-71

Dayton, P. K. (1971). Competition, disturbance and community organization: the provision and subsequent utilization of space in a rocky intertidal community. Ecol. Monogr. 41 351-389

Denley, E. J., Underwood, A. J. (1979). Experiments on factors influencing settlement, survival, and growth of 2 species of barnacles in New South Wales. J. exp. mar. Biol. Ecol. 36 : 269-293

Gaines, S. D., Roughgarden, J. (1985). Larval settlement rate a leading determinant of structure in an ecological community of the marine intertidal zone. Proc. natn. Acad. Sci. USA 82: $3707-3711$

Gaines, S. D., Roughgarden, J. (1987). Fish in offshore kelp forests affect recruitment to intertidal barnacle populations. Science 235: 479-481

Grosberg, R. K. (1982). Intertidal zonation of barnacles: the influence of planktonic zonation of larvae on vertical distribution of adults. Ecology 63: 894-899

Havenhand, J. N., Svane, I. (1991). Roles of hydrodynamics and larval behaviour in determining spatial aggregation in the tunicate Ciona intestinalis. Mar Ecol. Prog. Ser. 68: 271-276

Jokiel, P. L. (1980). Solar ultraviolet radiation and coral reef epifauna. Science 207: 1069-1071

Keough, M. J., Downes, B. J. (1982). Recruitment of marine invertebrates: the role of active larval choices and early mortality. Oecologia (Berl.) 54: 348-352

Keough, M. J., Downes, B. J. (1986). Effects of settlement and post-settlement mortality on the distribution of the ascidian Trididemnum opacum. Mar. Ecol. Prog. Ser. 33: $279-285$

Menge, B. A. (1976). Organization of the New England rocky intertidal community: role of predation, competition, and environmental heterogeneity. Ecol. Monogr. 46: 355-393
Menzel, R. W. (1971). Checklist of the marine fauna and flora of the Apalachee Bay and St. George's Sound area, 3rd edn. Dept Oceanog., Florida State Univ., Tallahassee

Menzel, R. W., Hulings, N. C., Hathaway, R. R. (1958). Causes of depletion of oysters in St. Vincent Bar, Apalachicola Bay, Florida. Proc. natn. Shellfish. Ass. 48: 66-71

Menzel, R. W. Hulings, N. C., Hathaway, R. R. (1966). Oyster abundance in Apalachicola Bay, Florida, in relation to biotic associations influenced by salinity and other factors. Gulf Res. Rep. 2: 73-96

Menzel, R. W.. Nichy, F. E. (1958). Studies of the distribution and feeding habits of some oyster predators in Alligator Harbor, Florida. Bull. mar. Sci. 8: 125-145

Millar, R. H. (1971). The biology of ascidians. Adv. mar. Biol. 9: $1-100$

Mook, D. (1980). Seasonal variation in species composition of recently settled fouling communities along an environmental gradient in the Indian River Lagoon, Florida. Estuar. coast. mar. Sci. 2: 573-581

Mook, D. (1983a). Indian River fouling organisms, a review. Florida Sci. 46: 162-167

Mook, D. (1983b). Responses of common fouling organisms in the Indian river, Florida, to various predation and disturbance intensities. Estuaries 6: 372-379

Nichy, F. E., Menzel, R. W (1960). Mortality of intertidal and subtidal oysters in Alligator Harbor, Florida. Proc. natn. Shellfish Ass. 51: 33-41

Odum, W. E., Mclvor, C. C., Smith, T. J. (1982). The ecology of the mangroves of South Florida: a community profile. U.S. Fish. Wild Serv, Washington, D.C.

Olson, R. R. (1983). Ascidian-Prochloron symbiosis: the role of larval photoadaptations in midday release and settlement. Biol. Bull. mar biol. Lab., Woods Hole 165: 221-240

Olson, R. R. (1985). The consequences of short-distance larval dispersal in a sessile marine invertebrate. Ecology 66: 30-39

Olson, R. R., McPherson, R. (1987). Potential vs. realized larval dispersal: fish predation on larvae of the ascidian Lissoclinum patella (Gottschaldt). J. exp. mar Biol. Ecol. 110: 245-256

Paine, R. T. (1974). Intertidal community structure: experimental studies on the relationship between a dominant competitor and its principal predator. Oecologia (Berl.) 15: 93-120

Paine, R. T., Suchanek, T H. (1983). Convergence of ecological processes between independently evolved competitive dominants: a tunicate-mussel comparison. Evolution 37: $821-831$

Raimondi, P. T. (1988). Settlement cues and determination of the vertical limit of an intertidal barnacle. Ecology 69: 400-407

Raimondi, P. T. (1991). Settlement behavior of Chthamalus anisopoma larvae largely determines the adult distribution. Oecologia 85: 349-360

Rudloe, J. (1971). The erotic ocean. World Publishing, New York

Stephenson, T A., Stephenson, A. (1972). Life between tidemarks on rocky shores. W. H. Freeman and Co., San Francisco

Stoner, D. S. (1990). Recruitment of a tropical colonial ascidian: relative importance of pre-settlement vs. post-settlement processes. Ecology 71: 1682-1690

Strathmann, R. R., Branscomb, E. S., Vedder, K. (1981). Fatal errors in set as a cost of dispersal and the influence of intertidal flora on set of barnacles. Oecologia (Berl.) 48: 13-18

Sutherland, J. P. (1978). Functional roles of Schizoporella and Styela in the fouling community at Beaufort, North Carolina. Ecology 59: 257-264 
Sutherland, J. P., Karlson, R. H. (1977). Development and stability of the fouling community at Beaufort, North Carolina. Ecol. Monogr. 47. 425-446

Svane, I. (1987). On larval behaviour and post-metamorphic mortality of Ascidia mentula O.F. Müller. Ophelia 27: $87-100$

Svane, I., Young, C. M. (1989). The ecology and behavior of ascidian larvae. Oceanogr. mar. Biol. A. Rev. 27: 45-90

Tursi, A., Matarrese, A. (1981). Phenomena of settling in Styela plicata (Les.). Mem. Biol. mar Oceanogr 11: $117-130$

Underwood, A. J. (1980). The effects of grazing by gastropods and physical factors on the upper limits of distribution of intertidal macroalgae. Oecologia (Berl.) 46: 201-213

Underwood, A. J., Fairweather, P. G. (1986). Intertidal communities: do they have different ecologies or different ecologists? Proc. Ecol. Soc. Aust. 14: 7-16

Yamaguchi, M. (1970). Spawning periodicity and settling time in ascidians, Ciona intestinalis and Styela plicata. Rec. oceanogr. Wks Japan 10: 147-155

This article was presented by P.W. Sammarco, Chauvin, Louisiana, USA
Young, C. M. (1985). Abundance patterns of subtidal solitary ascidians in the San Juan Islands, Washington, as influenced by food preferences of the predatory snail Fusitriton oregonensis. Mar. Biol. 84: 309-321

Young, C. M. (1989). Distribution and dynamics of an intertidal ascidian pseudopopulation. Bull. mar. Sci. 45: 288-303

Young, C. M. (1990). Larval predation by epifauna on temperate reefs: scale, power and the scarcity of measurable effects. Aust. J. Ecol. 15: 413-426

Young, C. M., Chia, F.-S. (1984). Microhabitat-associated variability in survival and growth of subtidal solitary ascidians during the first 21 days after settlement. Mar. Biol. 81: $61-68$

Young, C. M., Chia, F.-S. (1987). Abundance and distribution of pelagic larvae as influenced by predation, behavior, and hydrographic factors. In: Giese, A. C., Pearse, J. S., Pearse, $\mathrm{V}$ B. (eds.) Reproduction in marine invertebrates. Vol. 9, General aspects: seeking unity in diversity. Blackwell Scientific, Palo Alto, California, p. 385-463

Manuscript first received: April 10, 1991

Revised version accepted: January 7, 1992 